\title{
Politics of Law of Social Security of Passenger Accidents Construction of State Responsibility
}

\section{Maryanto*) and Ahmad Suhasan ${ }^{* *}$ )}

*) Faculty of Law, Universitas Islam Sultan Agung Semarang, E-mail : maryanto@unissula.ac.id

**) Student of Master of Law, Faculty of Law, Universitas Islam Sultan Agung Semarang, E-mail : ahmadsuhasan24@gmail.com

\begin{abstract}
.
The role of the presence of the state is important so that the implementation of social security from the government to the community is managed from compulsory contributions and community contributions. Management and control of the funds are submitted to the State Owned Enterprises (BUMN) PT. Jasa Raharja. This research method is normative juridical (normative law research) using normative legal studies in the form of legal behavior products. Research findings: (1) The Political Law of Social Security for Passenger Accidents and Road Traffic Accidents provides an overview of the Insurance business that has been managed so far PT. Jasa Raharja is a social insurance program that can be organized by BUMN, so PT. Jasa Raharja as a state-owned company is the only provider of social security insurance for passenger accidents and road traffic accidents. (2) Barriers to adjusting the implementation of the Social Security Program based on Act No. 40 of 2014 concerning Insurance in terms of regulation between Act No. 33 and 34 of 1964 with Act No. 40 of 2014 concerning Insurance, the institutional provisions of article 89 of the Insurance Law are implemented, so there is a fundamental change in the administration of the mandatory insurance coverage for passenger accidents and road traffic accidents.

Keywords : Political Law; PT. Jasa Raharja; Act No. 40 of 2014.
\end{abstract}

\section{Introduction}

The state must provide guarantees for accident victims making the role of the state very important. Because accident victims can come from various walks of life, especially from the middle to lower class, the state must be present to provide assistance to the community. The form of assistance or guarantee given related to traffic accidents, especially those related to road traffic, is in the form of passenger accident insurance. Thus this is in accordance with Article 34 of the 1945 Constitution of the Republic of Indonesia which states that, "The state develops a social security system for all people and empowers weak and incapacitated people according to human dignity". ${ }^{\text {So }}$ that in the explanation of the article the government is obliged to provide social security as a state obligation to participate in providing social security for the community.

The implementation of social security is manifested in a passenger accident insurance program based on Act No. 33 of 1964 concerning Compulsory Accident Insurance Funds for Passengers and Act No. 34 of 1964 concerning Compulsory Accident Insurance Funds. In this implementation, basically it is a social security

\footnotetext{
${ }^{1}$ Article 34 of the 1945 Constitution of the Republic of Indonesia.
} 
from the government to the community which is managed from compulsory contributions and obligatory public contributions. Management and control of the funds are submitted to State Owned Enterprises (BUMN). BUMN here is PT. Jasa Raharja as the sole manager in providing social security for passenger accidents and road traffic accidents. The existence of PT. Jasa Raharja then cannot be seen solely as an insurance company in terms of passenger accidents and road traffic accidents.

The aim of the implementation is to fulfill the state's obligation to fulfill the right to social security which is guaranteed by Article $28 \mathrm{H}$ paragraph (3) of the 1945 Constitution of the Republic of Indonesia that "Every person has the right to social security which enables his complete development as a dignified human being." ${ }^{2}$ The state's responsibility to develop a social security system is actually intended for weak and underprivileged people. So it is important for the state in the implementation of social security to not only ensure the availability of good facilities, but also to have services that are available so that people's rights can be fulfilled properly.

The existence of Act No. 40 of 2014 concerning Insurance has undergone a change in the implementation of insurance business activities in Indonesia. However, it also raises a number of questions regarding several legal principles, including those contained in Article 39 requiring compulsory insurance to be carried out in a competitive manner and the provisions of Article 89 in its elucidation order the implementation of compulsory insurance including passenger accident insurance and road traffic accident insurance based on Act No. 33 of 1964 and Act No. 34 of 1964 which must be adjusted in the implementation of insurance activities based on Act No. 40 of 2014 concerning Insurance. By observing Articles 39 and 89, will the administration of the insurance fund be compulsory based on Act No. 33 of 1964 and Act No. 34 of 1964 which is a social insurance (state owned) is carried out competitively in the sense that it can be carried out by a private insurance company. This problem leads to the importance of the presence of the state in providing social security to people who experience general accidents. So that the presence of the state should not be replaced by the private sector, in this case private companies.

Article 1 Paragraph (4) of Act No. 40 of 2014 concerning Insurance explains that: "Insurance business is all business related to insurance or risk management services, risk reinsurance, marketing and distribution of insurance products or sharia insurance products, insurance consulting and broking, sharia insurance, reinsurance, or sharia reinsurance, or assessment of insurance or sharia insurance losses. ${ }^{3}$ The definition of insurance according to Article 246 of the Indonesian Commercial Code (KUHD): "Insurance or coverage is an agreement, whereby an insurer binds himself to the insured by receiving a premium, to compensate him for a loss, damage or loss of expected profit, which he may suffer due to an unspecified event "4

Elucidation of Article 89, bringing together the UUP and Act No. 33 and Act No. 34 of 1964 in the form of an obligation to adjust the implementation of the Compulsory Accident Insurance Fund for Passenger Accidents and the Road Traffic

\footnotetext{
${ }^{2}$ Article $28 \mathrm{H}$ paragraph (3) of the 1945 Constitution of the Republic of Indonesia.

${ }^{3}$ Article 1 paragraph (4) of Act No. 40 of 2014 concerning Insurance.

${ }^{4}$ Buku I Bab 9 Pasal 246 Kitab Undang-undang Hukum Dagang (KUHD) Republik Indonesia.
} 
Accident Fund with the implementation of insurance based on Act No. 40 of 2014 concerning Insurance. The provisions of Article 89, if implemented, will result in a fundamental change in the administration of the Compulsory Passenger Accident Coverage Fund and the Road Traffic Accident Fund. That so far, the two insurances must be carried out by the state company (state-owned company) PT. Jasa Raharja (Persero). Then if it is adjusted to the provisions of Article 39 paragraph (1) and the explanation of Article 89, the implementation of the Compulsory Insurance Fund is based on Act No. 33 and Act No. 34 of 1964 must be implemented on a competitive basis. Therefore, it is understandable that PT. Service Raharja (Persero), a stateowned company, will end up implementing a single social security (monopoly).

\section{Research methods}

This type of research is field research that is, research conducted directly in the field, with the hope that researchers can obtain information and data as close as possible to conditions in the field, so that the results of field research can make good use of the results. ${ }^{5}$ The approach in this research uses legal research juridical normative (legal normative research), namely research conducted by reviewing the laws and regulations that apply or are applied to a particular legal issue.

The research specification uses descriptive analytical. Sources of data used in this study include; Primary Data and Secondary Data, Primary Data are the words and actions of the people being observed or interviewed. ${ }^{6}$ While secondary data is data consisting of 3 legal materials, including primary legal materials, secondary legal materials, and tertiary legal materials. Method data analysis uses descriptive analysis that can be used with a qualitative approach to primary and secondary data, so that it uses a deductive mindset that analyzes the Legal Politics of Social Security for Road Traffic Accident Victims based on Act No. 40 of 2014 in the Context of Realizing State Responsibility. After data collection has been collected, the data is analyzed as necessary in order to obtain mature and accurate data. ${ }^{7}$

\section{Results and Discussion}

\subsection{Political Law of Social Security for Passenger Accidents and Road Traffic Accidents}

The legal reform of the Indonesian nation is marked by amendments to the 1945 Constitution of the Republic of Indonesia, up to 4 (four) changes. After the amendments to the 1945 Constitution of the Republic of Indonesia, the Indonesian constitutional system underwent very basic changes. Changes also bring structural changes and mechanisms to the government of the State, because a change in the constitution of a country means the old rules to new rules in carrying out this strictness.

One of the obvious implications seen in the amendment to the constitution is related to the problem of the Social Security System. This can be seen in Article 34

\footnotetext{
${ }^{5}$ Widi, Restu Kartiko. (2010). Asas Metodologi Penelitian. Yogyakarta: Graha Ilmu. p.52.

${ }^{6}$ Lexy J, Moleong. (2005). Metode Penelitian Kualitatif. Bandung: PT Remaja Roadkarya. p.144.

${ }^{7}$ Moleong. Op Cit. p.288.
} 
paragraph (2) of the 1945 Constitution states as follows: "The state develops a social security system for all the people and empowers the weak and underprivileged people according to human dignity. "8

Social security is also guaranteed in the United Nations Declaration on Human Rights of 1948 and confirmed in the ILO Convention Number 102 of 1952 which recommends all countries to provide protection for victims of accidents. Meanwhile, several Social Security Programs that have been implemented so far are laws that specifically regulate Social Security.

The existence of Act No. 33 of 1964 and Act No. 34 of 1964 in the Social Security System in Indonesia provides new changes with the birth of the social security law, namely Act No. 40 of 2014 concerning Insurance, which the law requires in the implementation of passenger accident social security is carried out in a competitive manner. Yet seeing so far, the implementation of road traffic accident social security is the responsibility of PT. Jasa Raharja in accordance with Act No. 33 and 34 in 1964.

Providing guarantees for accident victims is a very important role of the state and / or state responsibility. This is because victims of traffic accidents can come from various levels of society, especially from the middle to lower class. With these conditions, the state must be present to provide assistance. The form of assistance or guarantees provided regarding traffic accidents is in the form of insurance for passenger accidents and road traffic accidents.

The implementation of Social Security is basically social security from the government to the community which is managed from compulsory contributions and compulsory public contributions. Management and control of the funds are submitted to State Owned Enterprises (BUMN), namely PT. Jasa Raharja as a State Enterprise which is the sole player in the implementation of social security for passenger accidents and road traffic accidents. ${ }^{9}$ Therefore, the existence of PT Jasa Raharja cannot be seen solely as an insurance company in terms of passenger accidents and road traffic accidents. PT Jasa Raharja plays the role of the state presence or the embodiment of the state in providing social security for passenger accidents and road traffic accidents.

The emergence of Act No. 40 of 2014 concerning Insurance which replaces Act No. 2 of 1992. Act No. 40/2014 provides a foundation for the insurance industry and activities to accommodate the current developments. The existence of this law can provide social security to the community, so that the above program activities can be felt by the middle to lower class communities. Because a small part of the community has not received adequate protection. In addition, the implementation of these various Social Security Programs has not been able to provide fair and adequate protection to participants in accordance with the program benefits to which participants are entitled.

Article 1 number 32 Act No. 40 of 2014 states that: Compulsory Insurance Program is a program that is required by laws and regulations for all or certain groups in the community in order to obtain certain protection and risks, not including programs that are required by law to provide basic protection for the community with

8 The 1945 Constitution of Indonesia, and Amendments there of Article 34.

${ }^{9}$ Article 1, paragraph 3 of Act No. 2 of 1992 concerning Insurance Business. 
a cross-subsidization mechanism in determining benefits and premiums or contributions.

The general explanation of Act No. 40 of 2014 concerning Insurance states that: "This law also requires the implementation of a Compulsory Insurance Program, for example, legal liability insurance to third parties for motorized vehicles, in a competitive manner and allows the granting of fiscal facilities to individuals, households and / or micro, small and medium enterprises to encourage increased use of insurance or Sharia insurance for risk management."

Based on the provisions above, one of the Compulsory Insurance Programs is legal liability insurance to third parties for motorized vehicle drivers. Meanwhile, Social Insurance is defined as protection insurance for individuals against economic risks, the government participates or requires the participation of individuals who suffer losses. ${ }^{10}$ Another thing in Act No. 1992 concerning Insurance Business, an insurance program which is implemented compulsorily based on a law with the aim of providing basic protection for the welfare of the community is classified as a "social insurance" program. ${ }^{11}$ However, Act No. 2 of 1992 concerning Insurance Enterprises limits that the social insurance program can only be implemented by BUMN. ${ }^{12}$ Referring to the definitions and limitations on the implementation of social insurance, PT. Jasa Raharja as a BUMN is the only provider of Social Security insurance for passenger accidents and road traffic accidents. Thus, social security is basically the provision of government compensation which is managed from mandatory contributions and mandatory contributions from participants / the community, as well as the management, control of the funds being handed over to BUMN. In addition, the presence of Act No. 40 of 2014 concerning Insurance which replaces Act No. 2 of 1992 concerning Insurance Business, as if it casts a social insurance concept that has been implemented by PT. Jasa Raharja. Even though in Act No. 40 of 2014 concerning Insurance is not known as Social Insurance but the Compulsory Insurance Program. The Compulsory Insurance Program is defined as follows: Programs that are required by laws and regulations for all or certain groups in society in order to receive certain protection and risks, do not include programs that are required by law to provide basic protection for the community by means of a cross-subsidy mechanism in determining benefits and premiums or contributions. ${ }^{13}$ If we look back at the definition of that, what is meant by Act No. 40 of 2014 concerning Insurance as compulsory insurance, not social insurance. ${ }^{14}$

\subsection{Barriers to Adjustment of Social Security Program Implementation}

On 17 October 2014, the Government of the Republic of Indonesia has enacted Act No. 40 of 2014 concerning Insurance. This law is intended to create a healthy, trustworthy and competitive insurance industry. This arrangement is in

\footnotetext{
10 Nasution, Binsar. dkk. Jaminan Sosial Dalam Perspektif UU No.40 Tahun 2014 Tentang Perasuransian. (Jakarta: Spora Consultant, 2016). p.3.

11 Article 1, paragraph 3 of Act No. 2 of 1992 concerning Insurance Business.

12 Article 4, paragraph 1 of Act No. 2 of 1992 concerning Insurance Business.

13 Ibid, Article 1 paragraph 32 Act No. 40 of 2014 concerning Insurance.

${ }_{14}$ Umam, Chairul. Melihat hal-hal krusial dalam wajiah baru Undang-undang Perasuransian. Artikel, Jurnal Online. p.6.
} 
insurance activities in encouraging national development through the support of public insurance companies in facing the risks faced. The arrangement of insurance business activities in Act No. 40 of 2014 concerning Insurance, is not only a voluntary activity, but also a compulsory insurance program. Article 39 paragraph (1) stipulates that the compulsory insurance program must be administered in a competitive manner. It can be understood that the implementation of the insurance program must be left to the market mechanism by including all insurance company institutions, ${ }^{15}$

Structuring financial institutions so that they are able to carry out their respective functions and duties is the first step towards achieving increased implementation of national development required by the community and the business world in encouraging economic growth, equitable development, and including expanding business opportunities or increasing employment, especially in the insurance sector. In order to strengthen the implementation of an insurance company, it is necessary to give wide opportunities to any party wishing to conduct business in the insurance sector which is carried out in a healthy, responsible manner, and does not neglect the interests of the general public and the interests of the insured or policy holder.

In fact, the implementation experienced several obstacles in the implementation of Act No. 40 of 2014, namely: (1) In terms of regulation between Act No. 33 and 34 of 1964 with Act No. 40 of 2014 concerning Insurance, this can be seen if PT. Jasa Raharja (Persero) in implementing the mandatory coverage fund mandated by Act No. 33 and 34 of 1964 in which this law is a form of social security that is different from that of insurance companies in general. It is not ap propriate if all provisions of the Insurance Law are applied to Act No. 33 and 34 of 1964 without regard to special circumstances in the two forms of insurance or coverage as social security. (2) From an institutional perspective, if the provisions of article 89 of the Insurance Law are implemented, then there is a fundamental change in the administration of the mandatory insurance coverage for passenger accidents and road traffic accidents. So far, the two insurance funds must be held by a state company (BUMN). If it has to be adjusted to the Insurance Law, it will be done competitively. In other words, the state monopoly through BUMN will end with the opening of a competitive, opportunity for private insurers to implement both mandatory insurance funds. (3) In terms of fund management, in practice the implementation of Act No. 33 and 34 of 1964 in the payment of mandatory donations for vehicle owners carried out simultaneously with vehicle tax payments carried out through SAMSAT involving the central government, local governments, the police and PT. Jasa Raharja. This is if the mandatory motor vehicle documents cannot be issued if the motor vehicle owner does not pay the mandatory contribution payment in advance. This system provides assurance on the obligation of vehicle owners to make mandatory contribution payments. Then in the mandatory insurance fund based on Act No. 33 and 34 of 1964 are not based on an agreement or agreement but are applied in statutory regulations (public law). Whereas in the Insurance Law Article 28 of the Insurance Law states that the

15 Nasution, Binsar. dkk. (2016). Jaminan Sosial Dalam Perspektif UU No.40 Tahun 2014 Tentang Perasuransian. Jakarta: Spora Consultant. p.3. 
premium or contribution can be paid directly by the policy holder or participant to the insurance company and an agreement is determined to the parties mentioned in the agreement (insurance policy).

\section{Closing}

That the Legal Politics of Social Security for Passenger Accidents and Road Traffic Accidents based on Act No. 40 of 2014 concerning Insurance provides a business description The insurance managed so far, namely PT. Jasa Raharja is a social insurance program that can be organized by BUMN, so PT. Jasa Raharja as a BUMN is the only provider of Social Security insurance for passenger accidents and road traffic accidents. This does not include programs that are required by law to provide basic protection for the community. Meant by Act No. 40 of 2014 concerning Insurance as compulsory insurance, not social insurance. The factors that become obstacles to the adjustment of the implementation of the Social Security Program based on Act No. 40 of 2014 concerning Insurance, are several factors: (1) In terms of regulation between Act No. 33 and 34 of 1964 with Act No. 40 of 2014 concerning Insurance, (2) In terms of the institutional provisions of article 89 of the Insurance Law, there is a fundamental change in the implementation of the mandatory insurance fund for passenger accidents and road traffic accidents. So far, the two insurance funds must be held by a state company (BUMN). (3) In terms of fund management, in practice the implementation of Act No. 33 and 34 of 1964 in the payment of compulsory contributions. Meanwhile, Article 28 of the Insurance Law states that premiums or contributions can be paid directly by policyholders or participants.

\section{References}

\section{Journal:}

[1] Chairul umam, Melihat hal-hal krusial dalam wajiah baru Undang-undang Perasuransian, Artikel, Jurnal Online Jurnal Rechtsvinding, https://rechtsvinding.bphn.go.id/jurnal_online/MELIHAT\%20HAL\%20KRUSI AL\%20DALAM\%20WAJAH\%20BARU\%20UNDANGUNDANG\%20PERASURANSIAN.pdf

\section{Book:}

[1] Ali, Zainudin. (2009). Metodologi Penelitian Hukum, Jakarta: Sinar Grafika.

[2] Moleong, Lexy J, 2005, Metode Penelitian Kualitatif, Bandung: PT Remaja Roadkarya.

[3] Nasution, Binsar. dkk. (2016). Jaminan Sosial Dalam Perspektif UU No.40 Tahun 2014 Tentang Perasuransian. Jakarta: Spora Consultant

[4] Soejono and H Abdurahman. (2008). Metode Penelitian Hukum. Jakarta: Rineka

[5] Soekanto Soerjono. (1986). Pengantar Penulisan Hukum. Jakarta: UI Press.

[6] Widi, Restu Kartiko. (2010). Asas Metodologi Penelitian. Yogyakarta: Graha Ilmu. 


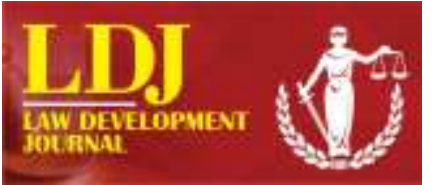

Law Development Journal

ISSN : 2747-2604

Volume 3 Issue 1, March 2021, (30 - 37)

\section{Regulations:}

[1] The 1945 Constitutional of Indonesia

[2] Indonesian Commercial Code (KUHD)

[3] Act No. 2 of 1992 concerning Insurance Business

[4] Act No. 40 of 2014 concerning Insurance 